\title{
South Slavic Language
}

National Cancer Institute

\section{Source}

National Cancer Institute. South Slavic Language. NCI Thesaurus. Code C161858.

A branch of the Slavic languages spoken mainly in the Balkans. 